\title{
Mental health consequences of COVID-19 media coverage: the need for effective crisis communication practices
}

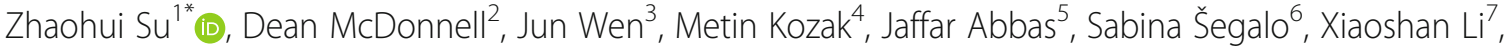 \\ Junaid Ahmad ${ }^{8}$, Ali Cheshmehzangi ${ }^{9,10}$, Yuyang Cai ${ }^{11,12}$, Ling Yang ${ }^{13}$ and Yu-Tao Xiang ${ }^{14^{*}}$
}

\begin{abstract}
During global pandemics, such as coronavirus disease 2019 (COVID-19), crisis communication is indispensable in dispelling fears, uncertainty, and unifying individuals worldwide in a collective fight against health threats. Inadequate crisis communication can bring dire personal and economic consequences. Mounting research shows that seemingly endless newsfeeds related to COVID-19 infection and death rates could considerably increase the risk of mental health problems. Unfortunately, media reports that include infodemics regarding the influence of COVID-19 on mental health may be a source of the adverse psychological effects on individuals. Owing partially to insufficient crisis communication practices, media and news organizations across the globe have played minimal roles in battling COVID-19 infodemics. Common refrains include raging QAnon conspiracies, a false and misleading "Chinese virus" narrative, and the use of disinfectants to "cure" COVID-19. With the potential to deteriorate mental health, infodemics fueled by a kaleidoscopic range of misinformation can be dangerous. Unfortunately, there is a shortage of research on how to improve crisis communication across media and news organization channels. This paper identifies ways that legacy media reports on COVID-19 and how social media-based infodemics can result in mental health concerns. This paper discusses possible crisis communication solutions that media and news organizations can adopt to mitigate the negative influences of COVID-19 related news on mental health. Emphasizing the need for global media entities to forge a fact-based, person-centered, and collaborative response to COVID-19 reporting, this paper encourages media resources to focus on the core issue of how to slow or stop COVID-19 transmission effectively.
\end{abstract}

Keywords: COVID-19, Coronavirus, Mental health, Crisis communication, Infodemic, Misinformation, Disinformation

\section{Background}

Similar to pandemics like the 1918-1919 influenza outbreak, the Coronavirus Disease 2019 (COVID-19) is a once-in-a-century event [1]. Different from previous global health crises, the impact of COVID-19 is not distant,

\footnotetext{
*Correspondence: szh@utexas.edu; ytxiang@um.edu.mo

${ }^{1}$ Center on Smart and Connected Health Technologies, Mays Cancer Center, School of Nursing, UT Health San Antonio, 7703 Floyd Curl Drive, San Antonio, TX 78229, USA

${ }^{14}$ Unit of Psychiatry, Institute of Translational Medicine, Faculty of Health Sciences; \& Center for Cognition and Brain Sciences, University of Macau, Macao SAR, China

Full list of author information is available at the end of the article
}

rather, it is close to home, catastrophic, and ongoing-as of December 1st, approximately 63.3 million confirmed cases and 1.47 million deaths were known to be caused by COVID-19 [2]. The scope and severity of the pandemic have further fueled a global mental health crisis, especially among underserved populations like older adults, healthcare professionals, and women [3]. It is estimated that in October 2020, more people in Japan have died of suicide (2153) than COVID-19 (2087) [4]. Compared to numbers in 2019 , there was a $82.6 \%$ rise among Japanese women who died of suicide in October, 2020 [4].

\section{BMC}

(c) The Author(s). 2021 Open Access This article is licensed under a Creative Commons Attribution 4.0 International License, which permits use, sharing, adaptation, distribution and reproduction in any medium or format, as long as you give appropriate credit to the original author(s) and the source, provide a link to the Creative Commons licence, and indicate if changes were made. The images or other third party material in this article are included in the article's Creative Commons licence, unless indicated otherwise in a credit line to the material. If material is not included in the article's Creative Commons licence and your intended use is not permitted by statutory regulation or exceeds the permitted use, you will need to obtain permission directly from the copyright holder. To view a copy of this licence, visit http://creativecommons.org/licenses/by/4.0/ The Creative Commons Public Domain Dedication waiver (http://creativecommons.org/publicdomain/zero/1.0/) applies to the data made available in this article, unless otherwise stated in a credit line to the data. 
Though almost a year has passed since the first COVID-19 outbreak, epidemiologists are still working on understanding COVID-19's clinical features [5]. In addition to its unknown viral characteristics, a key contributor fueling the destructive power of COVID-19 is its unprecedented transmissibility [6-8]. COVID-19's ability to spread fast and far in a short period is rare, even among other pandemics [6-8]. This rapid pace of transmission, coupled with consequent spikes in infection and death, has caused a range of physical and psychological issues in individuals across the globe [9]. Challenging to identify or fully "cure", mental health services were facing numerous, but resource-constraining pandemics like COVID-19 have exacerbated these issues [9-12].

Mental health is "a state of well-being in which the individual realizes his or her own abilities, can cope with the normal stresses of life, can work productively and fruitfully, and is able to make a contribution to his or her community" [13]. Amid a global crisis, mental health issues can have severe health consequences on personal and population health, ranging from anxiety, distress or depression, to suicidal ideation or suicide [3, 14, 15]. COVID-19 has been a source of complex, multifaceted stress for many [16-22]. The fears and uncertainty associated with the virus, together with the anxiety and stress following from lockdowns and social distancing mandates, have exacerbated mental health issues to varying degrees throughout society [23-25]. Not only diminishing the mental health and well-being of individuals, COVID-19 has also limited the services people can access; the rationing of medical resources during the COVID-19 pandemic has instigated a restructuring and repurposing across mental health institutions to deal with the pandemic [26-28]. Well-intentioned measures, such as lockdowns and social distancing, have further diminished access to mental health services [10], with many providers forced to close; leaving people little to no access to on-site assistance [26-28].

In addition to (1) the fear and uncertainty associated with COVID-19, (2) the anxiety and distress caused by lockdowns and social distancing mandates, and (3) limited access to mental health services [23-25], the unending barrage of news from legacy media outlets and social media platforms has further complicated the situation $[18,29,30]$. Media attention has disproportionately directed toward the COVID-19 infodemic, with little consideration for how pandemic-related media coverage might influence people's mental health. Moreover, the misinformation and disinformation surrounding COVID-19 - ranging from a false and misleading "Chinese virus" narrative to using disinfectants to "cure" COVID-19 - has affected individuals' mental and physical health and well-being [18, 19, 29, 31, 32]. Although some useful insight is available, scarce research has explored ways to mitigate the mental health consequences of COVID-19 media coverage.

Evidence shows that in times of global crisis such as COVID-19, crisis communication can, cost-effectively, address multifaceted issues. Crisis communication refers to "the collection, processing, and dissemination of information required to address a crisis situation" [33]. Though many developments of the field of crisis communication occurred in the past decades (e.g., the situational crisis communication theory developed by Timothy Coombs in 1995), crisis communication has a long history and is often contributed to eminent public figures such as Caesar and Confucius [34-37]. With the help of exemplar (e.g., Johnson \& Johnson's effective management of the Cyanide-Laced Tylenol Capsules crisis), as well as inadequate crisis communication practices (e.g., the United States government's mismanagement of Hurricane Katrina), a growing body of work has acknowledged crisis communication's role in mitigate negative impacts of adverse events [38-40]. Therefore, to address this research gap, this paper aims to identify areas where legacy media reports on COVID-19 and social media-fueled infodemics can harm people's mental health. This paper outlines potential crisis communication solutions that media and news organizations can adopt to alleviate the mental health consequences of COVID-19 coverage.

\section{Coverage of COVID-19 by legacy media}

Legacy media encompasses "media originally distributed using a pre-internet medium (print, radio, television), and media companies whose original business was in pre-Internet media, regardless of how much of their content is now available online" [41]. Three forms of coverage can broadly classify the impact of legacy media coverage of COVID-19 on people's mental health issues: (1) balanced, fact-based, and truth-oriented; (2) biased and misleading; and (3) false and dishonest.

\section{Balanced, fact-based, and truth-oriented COVID-19 media coverage}

COVID-19 media coverage is inherently harmful; the disease represents an ongoing, deadly pandemic [2]. This intrinsic negativity, which naturally transfers to media coverage of the virus, could cause mental health issues [42]. Research on media effects has long documented that negative news can lead to mild to severe mental health issues among consumers [42]. Importantly, due to the scale and severity of COVID-19, media attention has been disproportionately focused on pandemic-related news, which could further affect individuals already facing more significant mental health challenges [42]. It is important to note that while balanced, fact-based, and 
truth-oriented COVID-19 media coverage might be difficult to achieve, it is important that media organizations, as pillars of the Fourth Estate [43], strive to meet these standards to their best abilities.

\section{Biased and misleading COVID-19 media coverage}

When news is biased and misleading, the adverse effects of COVID-19 media coverage on personal and population health and well-being could be more pronounced [44-46]. Previous studies found that right-leaning media outlets often issue biased and misleading reports on COVID-19 [46], which could, in turn, facilitate the spread of misinformation on the virus. Analysis of a sample of 38 million media reports from January 1 to May 25, 2020 shows that a staggering of $84 \%$ of misinformation distributed by legacy media was neither challenged or fact-checked before they reached the public, effectively exposing countless number of people to misinformation, such as "miracle cures" or the "Democratic Party hoax," that could result in substantial human and economic consequences [47]. It is also important to note that fear and panic generated by COVID-19 related misinformation could have a long-lasting effect on people's mental health that outlives COVID-19 media cycles [48].

\section{False and dishonest COVID-19 media coverage}

Perhaps the most problematic type of media coverage on COVID-19 involves content that is false and dishonest [18-21]. While legacy media practitioners uphold the founding pillars of the industry, journalistic values and ethical standards, the prevalence of narratives referring to the "Wuhan virus," "Chinese virus," and "China virus" in legacy media reports on COVID-19 suggests that some outlets are fully capable of producing baseless, and sensational news [18-21]. Directly associating a group of people, nation, and entire race to a virus will inevitably evoke substantial mental health concerns among those targeted [18-21].

Another irreversible negative effect of legacy media's instigation of "fake news" is the deterioration of public trust around COVID-19 [49]. It is challenging to predict what might happen if people decide to ignore COVID19 information disseminated through legacy media outlets, where health experts and government officials share the latest developments related to the virus. What is not difficult to imagine is the human and economic consequences tied to a deliberately "ignorant" public; the results could be catastrophic [50].

\section{COVID-19 infodemics and social media}

COVID-19 infodemics are growing at a pandemic rate [51]. Infodemics involve the purposeful spread of misinformation and disinformation via the media, particularly on social media platforms. COVID-19 infodemics can detract from health experts' efforts, fuelling public fear, uncertainty, and mistrust, which could have grave personal and economic consequences [51-56]. Infodemics involve an array of topics on which misinformation and disinformation are publicized through tweets and Facebook posts, oftentimes powered by interested individuals or groups with ulterior political and economic interests $[55,57]$. Typical slants include QAnon conspiracies, the aforementioned "Chinese virus" narrative, and promoting the use of disinfectants to "cure" COVID-19 [5156].

Not all COVID-19 infodemics are created equal [58]. For example, the infodemic that promoted the ingestion of disinfectant to utilize its "health benefits" had direct physical and mental health implications to a number of individuals [31, 32, 58, 59]. Between May 1st and June 30th, 2020, there were 15 reported cases of methanol poisoning due to drinking disinfectant; of these cases, four individuals died, and three were discharged with visual impairment [59]. Still, others may mistakenly trust U.S. leaders' "sarcastic" remarks on COVID-19, which are repeatedly aired on legacy media and various other social media outlets $[60,61]$.

Resource constraints are a hallmark of COVID-19, and media resources are no exception. COVID-19 infodemics, along with smear campaigns endorsed by traditional media outlets, are an outrageous waste of public resources-global media attention should be focused on the health and well-being of the public, mainly because the pandemic is ongoing. In times of global crisis, media resources require investment in the issue of the day: how to slow or stop the spread of COVID-19 [62]. Considering the prevalence of misinformation and disinformation on legacy media and social media platforms, interventions are urgently needed to dispel COVID-19 infodemics and ensure related media coverage does not lead to unintended consequences; effective crisis communication practices are one such approach [62-64].

\section{Crisis communication amid COVID-19}

In times of global pandemics such as COVID-19, crisis communication is indispensable in dispelling fear and uncertainty and unifying citizens in a collective fight against disease [62-64]. A fundamental attribution of crisis communication is that it is usually adopted as an emergency communication strategy when at least three crises are at play: (1) a crisis or unprecedented event with widespread personal and economic consequences (e.g., the COVID-19 pandemic); (2) a communication crisis that could prevent key stakeholders from working towards a solution (e.g., COVID-19 infodemics); and (3) a potential trust crisis either already present or in development, partially due to the first two crises (e.g., public trust crises). 
To address these triple crises, society at large must take several steps: (1) rapidly develop an evidence-based, tailored disaster preparedness plan with the potential to curb the pandemic; (2) carefully execute this plan with speed and precision; and (3) communicate this plan and corresponding procedures effectively to the public in a timely, transparent, and truth-oriented fashion (i.e., effective crisis communication). Overall, effectively sharing public health updates with society in a reasonable and honest manner is paramount.

In addition to providing the public with trustworthy information, proactive decisions are needed from media professionals, health experts, and government officials to ensure effective delivery of COVID-19 updates to the public (i.e., so as not to cause unintended consequences involving mental health). In other words, crisis communication during COVID-19, especially in light of the mental health consequences associated with relevant media coverage, should have three objectives: (1) to communicate credible and reliable COVID-19 information with the public in a timely, transparent, and truthoriented manner; (2) to eliminate misinformation and disinformation and halt connected infodemics; and (3) to ensure that the delivery of COVID-19 information to the public leads to no unintended consequences (i.e., mental health problems) (see Fig. 1).

\section{Communicate credible and reliable COVID-19 related information}

During the pandemic, many governments, such as the Chinese [65], Irish [66], Finnish [67], and Norwegien government [68], have managed to communicate COVID-19 strategies effectively with the public. Take the Chinese government for instance. Starting from the first outbreak, the Chinese government has been delivering timely COVID-19 updates that are (1) tailored to the general public's needs and wants to enhance relevancy; (2) disseminated via traditional and social media outlets to increase reach and impact; and (3) presented by key health and government officials to boost message credibility are available to the public daily [69-71]. Along with avoiding potential mental health issues, these crisis communication efforts also have the potential to dispel people's fear and uncertainty about COVID-19 and improve their compliance with pandemic-related health and safety procedures such as lockdowns and face mask mandates [69-71].

Unprecedented times call for unprecedented measures [30]. Technology companies, including Google, Twitter, Facebook, and TikTok, can disseminate credible and reliable COVID-19 information by developing tailored algorithms to promote search results, tweets, or posts written by vetted epidemiologists or other health experts. Doing so could initiate a movement to communicate credible, reliable COVID-19 information with the public in a timely, transparent, and truthfocused fashion. Notably, the way public-facing messages are designed, developed, and delivered (i.e., in a persuasive manner that is relatable to the public) also influences communication outcomes [72].

\section{Eliminating COVID-19 infodemics}

Relying on Health organizations and government agencies alone is not enough; all key stakeholders must be involved [69-71, 73]. Public health campaigns that target the dangers of COVID-19 infodemics require development, and information that educates individuals on how to avoid being a conduit of misinformation or disinformation is needed. Given that a considerable proportion of the public lack the health literacy needed to distinguish credible information from misinformation or disinformation [50], educational programs should be established to ensure that infodemics will become less prevalent both during COVID-19 and in the future.

Despite promising initiatives [74], media companies should assume a more significant role in controlling the spread of COVID-19 infodemics. Research shows that merely adding an accuracy reminder while people are perusing information online can substantially enhance their ability to identify fake news [75]. This finding is encouraging, as it suggests that effective measures to curb the spread of COVID-19 infodemics can be highly costeffective. In addition to making individual decisions, perhaps social media companies should organize a collaborative response, such as through a crowdsourced and widely shared "Infodemic Response Checklist" [53]. This effort would help the social media environment at large establish a better system to protect the public from the harm of COVID-19 infodemics.

Overall, health experts should lead in quelling COVID-19 infodemics. As top epidemiologists like Dr. Anthony Fauci have demonstrated, health experts need to be closely connected with their main "customers" or the general public to facilitate effective communication [76-78]. Health experts also need to be more participatory in the public health decision-making process; in so doing, less disinformation will be disseminated by government officials while more decisions will be grounded in scientific evidence.

\section{Fact-based and people-centered COVID-19 crisis communication strategy}

COVID-19 affects people of all demographics [79]. It is difficult not to form an opinion about an enduring pandemic that continues to threaten lives, livelihoods, and gross domestic product (GDP) [2]. However, given the personal and economic consequences tied to biased and misleading [44-46] or blatantly false and malicious [59- 


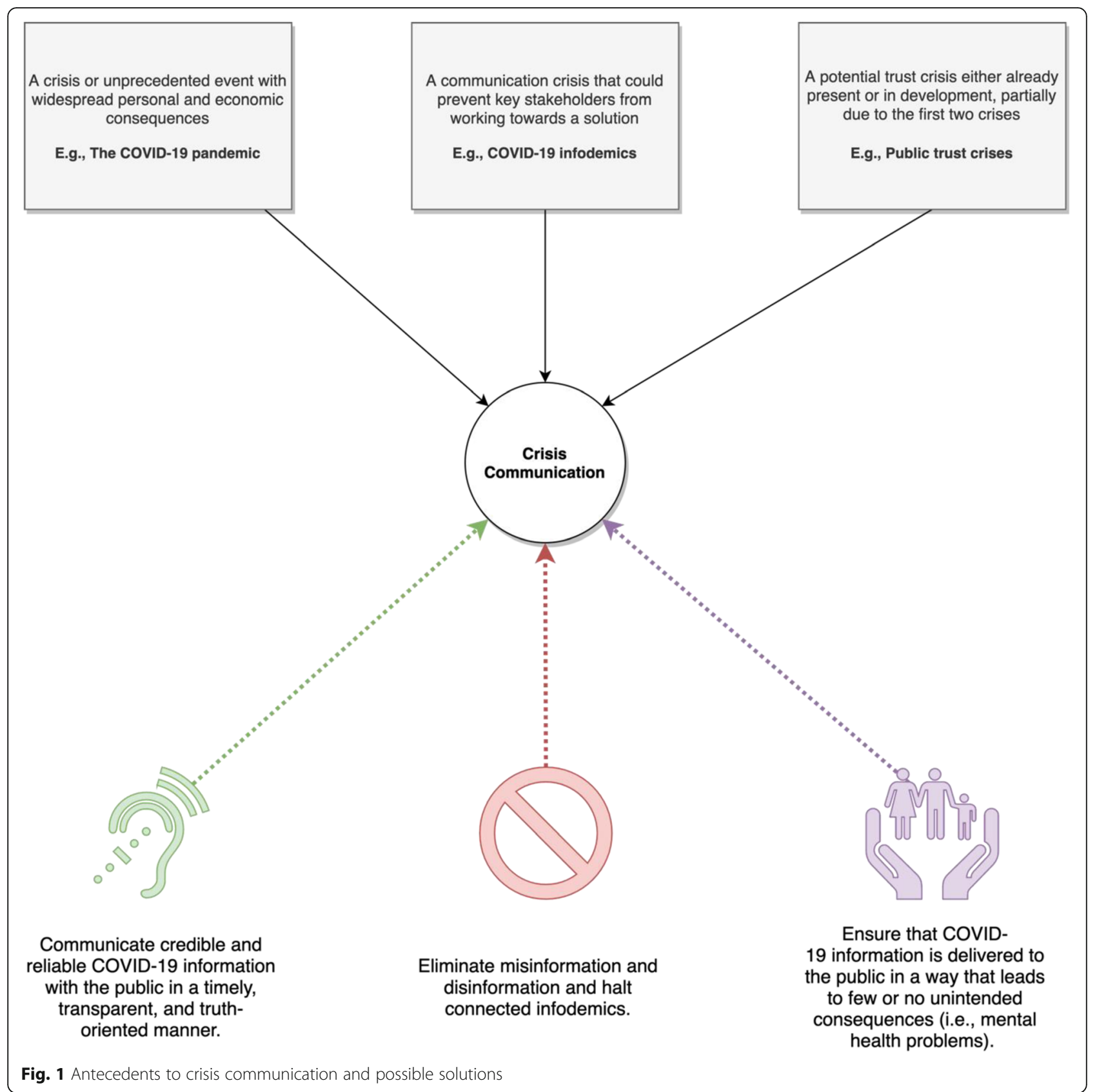

61] information, it is imperative for media professionals, health experts, and government officials to develop a fact-based, people-centered [17] COVID-19 crisis communication strategy. In the context of our study, factbased and people-centered crisis communication strategy is defined as communication endeavors deliver facts that matter to the people without framing the numbers or statistics based on personal views or ulterior motives (e.g., political gains or economic interests).

This way, well-intentioned information can be effectively delivered to the public without unintended consequences. It is important to note that educational interventions might be also needed for healthcare professionals, as a growing body of research shows that healthcare professionals often lack necessary levels of knowledge or risk perception needed to be vigilant about COVID-19 misinformation or disinformation [80-82]. Considering the important role healthcare professionals serve in patient education and the fact that many healthcare professionals also face substantial mental health challenges [83], educational interventions may be incremental in addressing infodemic-induced challenges these frontline workers face. 


\section{Concluding remarks}

Overall, in times of global pandemics like COVID-19, crisis communication can play a key part in reducing fear and uncertainty while inspiring a unified fight against health threats $[62-64,84]$. There has yet to be a national solution or unilateral communication during a pandemic, but considering the pronounced need for valuable media resources during COVID-19 for the greater good [50], health experts and media professionals have a responsibility to step up and put a stop to infodemics and smear campaigns. Stakeholders can battle inaccurate reporting with credible, reliable, and trustworthy information alongside well-developed tools and techniques in crisis communication. Transparency and legitimacy will ultimately help preserve people's health and well-being while bringing global media attention back to a genuine public health concern: how to prevent COVID-19 from spreading.

For future research directions, we believe there is a pronounced need to capitalize on media or communication resources to develop timely health solutions that have the potential to avoid immediate human consequences caused by COVID-19. Since the onset of the pandemic, in Turkey alone, approximately 100 musicians have committed suicide due to financial problems caused by COVID-19 [85]. We believe regional, national, and international health organizations and government agencies should invest more media resources into informing and emphasizing help and resources available to people amid the pandemic, compared with updates on COVID-19 infection and death tallies. In other words, it is important for media organizations to honor their roles as pillars of the Fourth Estate amid COVID19 [43], starting by pouring media resources into issues that matter to individuals' lives and livelihoods, rather than sensational reports that might boost Nielsen ratings, increase sales numbers, fuel infodemics, yet add limited benefits to public health and welfare [47].

\section{Abbreviations}

COVID-19: Coronavirus disease 2019; GDP: Gross domestic product

\section{Acknowledgements}

The authors wish to express their gratitude for the constructive input offered by the editor and reviewers.

\section{Authors' contributions}

ZS conceived the work, reviewed the literature, drafted, and edited the manuscript. DMD, JW, MK, JA, SS, XL, JA, AC, YC, LY, and YTX reviewed the literature and edited the manuscript. All authors approved the manuscript for submission.

\section{Funding}

None.

Availability of data and materials

No.
Ethics approval and consent to participate

Not applicable.

\section{Consent for publication}

Not applicable.

\section{Competing interests}

None.

\section{Author details}

${ }^{1}$ Center on Smart and Connected Health Technologies, Mays Cancer Center, School of Nursing, UT Health San Antonio, 7703 Floyd Curl Drive, San Antonio, TX 78229, USA. ²Department of Humanities, Institute of Technology Carlow, Carlow, Ireland R93 V960. ${ }^{3}$ School of Business and Law, Edith Cowan University, Perth, WA 6027, Australia. ${ }^{4}$ School of Tourism, Dokuz Eylül University, 35680 Foça, İzmir, Turkey. ${ }^{5}$ Antai College of Economics and Management, and School of Media and Communication, Shanghai Jiao Tong University, Shanghai 200240, China. ${ }^{6}$ Department of Microbiology, Faculty of Medicine, University of Sarajevo, 71000 Sarajevo, Bosnia and Herzegovina. ${ }^{7}$ Program of Public Relations and Advertising, Beijing Normal

University-Hong Kong Baptist University United International College, Zhuhai, Guangdong, China. ${ }^{8}$ Prime Institute of Public Health, Peshawar Medical College, Warsak Road, Peshawar 25160, Pakistan. ${ }^{9}$ Head of Department of Architecture and Built Environment; Professor of Architecture and Urban Design, Faculty of Science and Engineering, University of Nottingham Ningbo China, Ningbo, Zhejiang 315100, China. ${ }^{10}$ The Network for Education and Research on Peace and Sustainability (NERPS), Hiroshima University, Hiroshima, Japan. ${ }^{11}$ School of Public Health, Shanghai Jiao Tong University School of Medicine, Shanghai, China. ${ }^{12}$ China Institute for Urban Governance, Shanghai Jiao Tong University, Shanghai, China. ${ }^{13}$ Department of Geriatrics, Xinhua Hospital, Shanghai Jiao Tong University School of Medicine, Shanghai 200025, China. ${ }^{14}$ Unit of Psychiatry, Institute of Translational Medicine, Faculty of Health Sciences; \& Center for Cognition and Brain Sciences, University of Macau, Macao SAR, China.

Received: 3 October 2020 Accepted: 17 December 2020

Published online: 05 January 2021

\section{References}

1. Gates B. Responding to Covid-19 - a once-in-a-century pandemic? N Engl J Med. 2020;382(18):1677-9.

2. John Hopkins University. The COVID-19 global map. 2020 [cited 2020 October 25]; Available from: https://coronavirus.jhu.edu/map.html.

3. Wang $Y$, et al. Health care and mental health challenges for transgender individuals during the COVID-19 pandemic. Lancet Diabetes Endocrinol. 2020;8(7):564-5.

4. The Japan Times. Japan suicides rise as economic impact of coronavirus hits home. 2020 [cited 2020 December 1st]; Available from: https://www. japantimes.co.jp/news/2020/11/11/national/japan-suicide-rise-coronavirus/.

5. Bussani R, et al. Persistence of viral RNA, pneumocyte syncytia and thrombosis are hallmarks of advanced COVID-19 pathology. EBioMedicine. 2020;61:103104.

6. Fani M, Teimoori A, Ghafari S. Comparison of the COVID-2019 (SARS-CoV-2) pathogenesis with SARS-CoV and MERS-CoV infections. Future Virol. 2020. https://doi.org/10.2217/fvl-2020-0050.

7. Mahase E. Coronavirus: Covid-19 has killed more people than SARS and MERS combined, despite lower case fatality rate. BMJ. 2020;368:m641.

8. Wilder-Smith A, Chiew CJ, Lee VJ. Can we contain the COVID-19 outbreak with the same measures as for SARS? Lancet Infect Dis. 2020;20(5):e102-7.

9. Xiang Y-T, et al. Timely mental health care for the 2019 novel coronavirus outbreak is urgently needed. Lancet Psychiatry. 2020;7(3):228-9.

10. Mamun MA, Griffiths MD. First COVID-19 suicide case in Bangladesh due to fear of COVID-19 and xenophobia: possible suicide prevention strategies. Asian J Psychiatr. 2020;51:102073.

11. Sher $L$. The impact of the COVID-19 pandemic on suicide rates. QJM An Int J Med. 2020;113(10):707-712. https://doi.org/10.1093/qjmed/hcaa202.

12. Hughes $H$, et al. Uncomfortably numb: Suicide and the psychological undercurrent of COVID-19. Ir J Psychol Med. 2020;37(3):159-160. https://doi. org/10.1017/ipm.2020.49. 
13. World Health Organization. Promoting mental health: Concepts, emerging evidence, practice (Summary Report). Geneva: World Health Organization; 2004.

14. Goldmann E, Galea S. Mental health consequences of disasters. Annu Rev Public Health. 2014;35(1):169-83.

15. Gunnell D, et al. Suicide risk and prevention during the COVID-19 pandemic. Lancet Psychiatry. 2020;7(6):468-71.

16. Chung RY-N, Li MM. Anti-Chinese sentiment during the 2019-nCoV outbreak. Lancet. 2020;395(10225):686-7.

17. Chung RY-N, et al. Using a public health ethics framework to unpick discrimination in COVID-19 responses. Am J Bioeth. 2020;20(7):114-6.

18. Zheng Y, Goh E, Wen J. The effects of misleading media reports about COVID-19 on Chinese tourists' mental health: a perspective article. Anatolia. 2020;31(2):337-40

19. Wen J, et al. Effects of misleading media coverage on public health crisis: a case of the 2019 novel coronavirus outbreak in China. Anatolia. 2020a;31(2): 331-6.

20. Rovetta A, Bhagavathula AS. COVID-19-related web search behaviors and infodemic attitudes in Italy: Infodemiological study. JMIR Public Health Surveill. 2020;6(2):e19374.

21. Su Z, et al. Time to stop the use of 'Wuhan virus', 'China virus' or 'Chinese virus' across the scientific community. BMJ Glob Health. 2020;5(9):e003746.

22. Budhwani H, Sun R. Creating COVID-19 stigma by referencing the novel coronavirus as the "Chinese virus" on twitter: quantitative analysis of social media data. J Med Internet Res. 2020;22(5):e19301.

23. Mertens $\mathrm{G}_{\text {, et }}$ al. Fear of the coronavirus (COVID-19): predictors in an online study conducted in march 2020. J Anxiety Disorders. 2020;74:102258.

24. Tull MT, et al. Psychological outcomes associated with stay-at-home orders and the perceived impact of COVID-19 on daily life. Psychiatry Res. 2020; 289:113098.

25. Rossi R, et al. COVID-19 pandemic and lockdown measures impact on mental health among the general population in Italy. Front Psychiatry. 2020; 11:790.

26. Brown $\mathrm{E}$, et al. The potential impact of COVID-19 on psychosis: a rapid review of contemporary epidemic and pandemic research. Schizophr Res. 2020:222:79-87. https://doi.org/10.1016/j.schres.2020.05.005.

27. Fiorillo A, Gorwood P. The consequences of the COVID-19 pandemic on mental health and implications for clinical practice. European Psychiatry. 2020;63(1):e32.

28. Rajkumar RP. COVID-19 and mental health: a review of the existing literature. Asian J Psychiatr. 2020;52:102066.

29. Vazquez, M. Calling COVID-19 the "Wuhan Virus" or "China Virus" is inaccurate and xenophobic. 2020 [cited 2020 September 25]; Available from: https://medicine.yale.edu/news-article/23074/.

30. Tangcharoensathien $\mathrm{V}$, et al. Framework for managing the COVID-19 infodemic: methods and results of an online, crowdsourced WHO technical consultation. J Med Internet Res. 2020;22(6):e19659.

31. Yamey G, Gonsalves G. Donald Trump: a political determinant of covid-19. BMJ. 2020:369:m1643.

32. Reihani, $\mathrm{H}_{\text {., }}$ et al., Non-evidenced based treatment: An unintended cause of morbidity and mortality related to COVID-19. Am J Emerge Med, 2020: p. S0735-6757(20)30317-X.

33. Coombs WT. In: Coombs WT, Holladay SJ, editors. Parameters for crisis communication, in The handbook of crisis communication. Malden: WileyBlackwell; 2012. p. 17-53.

34. Heath RL, O'Hair HD. Handbook of risk and crisis communication. New York: Routledge; 2020

35. Heath RL. Best practices in crisis communication: evolution of practice through research. J Appl Commun Res. 2006;34(3):245-8.

36. Yu Th, Wen WC. Crisis communication in Chinese culture: A case study in Taiwan. Asian J Commun. 2003;13(2):50-64.

37. Huang Y-HC, Wu F, Cheng Y. Crisis communication in context: cultural and political influences underpinning Chinese public relations practice. Public Relat Rev. 2016:42(1):201-13.

38. Ulmer RR, Sellnow TL, Seeger MW. Effective crisis communication: Moving from crisis to opportunity. Thousand Oaks: Sage Publications; 2017.

39. Benoit WL. Image repair discourse and crisis communication. Public Relat Rev. 1997;23(2):177-86.

40. Roshan M, Warren M, Carr R. Understanding the use of social media by organisations for crisis communication. Comput Hum Behav. 2016;63:35061.
41. Miel P, Faris R. News and information as digital media come of age, Berkman Center for Internet and Society. Cambridge: Harvard University; 2008

42. Olagoke AA, Olagoke OO, Hughes AM, et al. Br J Health Psychol. 2020;25(4): e12427. https://doi.org/10.1111/bjhp.12427.

43. Schultz J. Reviving the fourth estate: Democracy, accountability and the media. U.K: Cambridge University Press; 1998.

44. Tasnim S, Hossain MM, Mazumder H. Impact of rumors and misinformation on covid-19 in social media. J Prev Med Public Health. 2020;53(3):171-4.

45. Simonov, A., et al., The persuasive effect of fox news: Non-compliance with social distancing during the covid-19 pandemic. 2020, National Bureau of Economic Research

46. Motta M, Stecula D, Farhart C. How right-leaning media coverage of COVID19 facilitated the spread of misinformation in the early stages of the pandemic in the U.S. Canadian Journal of Political Science. Revue Canadienne De Science Politique; 2020. p. 1-8.

47. Evanega S, et al. Coronavirus misinformation: Quantifying sources and themes in the COVID-19 'infodemic'. Ithaca: Cornell University; 2020.

48. Ahmad AR, Murad HR. The impact of social media on panic during the covid-19 pandemic in Iraqi Kurdistan: online questionnaire study. J Med internet Res. 2020;22(5):e19556.

49. Bunker D. Who do you trust? The digital destruction of shared situational awareness and the COVID-19 infodemic. Int J Inf Manag. 2020;55:102201-1. https://doi.org/10.1016/j.jijinfomgt.2020.102201.

50. Okan O, et al. Coronavirus-Related Health Literacy: A Cross-Sectional Study in Adults during the COVID-19 Infodemic in Germany. Int J Environ Res Public Health. 2020;17(15):5503. https://doi.org/10.3390/ijerph17155503.

51. Kouzy R, et al. Coronavirus goes viral: quantifying the COVID-19 misinformation epidemic on twitter. Cureus. 2020;12(3):e7255.

52. Orso D, et al. Infodemic and the spread of fake news in the COVID-19-era. Eur J Emerge Med. 2020. https://doi.org/10.1097/MEJ.0000000000000713.

53. Mheidly N, Fares J. Leveraging media and health communication strategies to overcome the COVID-19 infodemic. J Public Health Policy. 2020;41(4): 410-420. https://doi.org/10.1057/s41271-020-00247-w.

54. Zandifar A, Badrfam R. Iranian mental health during the COVID-19 epidemic. Asian J Psychiatr. 2020:51:101990.

55. Brennen JS, et al. Types, sources, and claims of Covid-19 misinformation. Reuters Institute. 2020:7:3.1.

56. Ferrara E. What types of COVID-19 conspiracies are populated by twitter bots? First Monday; 2020.

57. Dyer O. Trump claims public health warnings on covid-19 are a conspiracy against him. BMJ. 2020;368:m941.

58. Liu M, et al. Internet searches for unproven COVID-19 therapies in the United States. JAMA Intern Med. 2020;180(8):1116-8.

59. Yip $L$, et al. Serious adverse health events, including death, associated with ingesting alcohol-based hand sanitizers containing methanol-Arizona and New Mexico, may-June 2020. Morb Mortal Wkly Rep. 2020;69(32):1070.

60. Finset $A$, et al. Effective health communication - a key factor in fighting the COVID-19 pandemic. Patient Educ Couns. 2020;103(5):873-6. https://doi.org/ 10.1016/j.pec.2020.03.027.

61. Chary, M., et al., Geospatial correlation between COVID-19 health misinformation on social media and poisoning with household cleaners. medRxiv, 2020: p. 2020.04.30.20079657.

62. Fauci AS, Lane HC, Redfield RR. Covid-19 - navigating the uncharted. N Engl J Med. 2020:382(13):1268-9.

63. The Lancet. COVID-19: fighting panic with information. Lancet. 2020; 395(10224):537.

64. Wu AW, Connors C, Everly GS. COVID-19: peer support and crisis communication strategies to promote institutional resilience. Ann Intern Med. 2020;172(12):822-3

65. Li Y, Chandra Y, Kapucu N. Crisis coordination and the role of social media in response to COVID-19 in Wuhan, China. Am Rev Public Adm. 2020;50(67):698-705. https://doi.org/10.1177/0275074020942105.

66. Colfer B. Herd-immunity across intangible borders: Public policy responses to COVID-19 in Ireland and the UK. Europ Policy Analysis. 2020;6(2):203-225. https://doi.org/10.1002/epa2.1096.

67. Kabiraj S, Lestan F. COVID-19 outbreak in Finland: Case study on the management of pandemics. In: Babu G, Qamaruddin M, editors. International Case Studies in the Management of Disasters: Emerald Publishing Limited; 2020. p. 213-29. 
68. Christensen T, Lægreid P. Balancing governance capacity and legitimacy: how the Norwegian government handled the covid-19 crisis as a high performer. Public Adm Rev. 2020;80(5):774-9. https://doi.org/10.1111/puar. 13241.

69. Liu W, Yue X-G, Tchounwou PB. Response to the COVID-19 epidemic: The Chinese experience and implications for other countries. Int J Environ Res Public Health. 2020;17(7).

70. Trevisan M, Le LC, Le AV. The COVID-19 pandemic: a view from Vietnam. Am J Public Health. 2020;110(8):1152-3.

71. Hale T, et al. Variation in government responses to COVID-19. Blavatnik School of Government Working Paper; 2020. p. 31.

72. Chen $\mathrm{Q}$, et al. Unpacking the black box: how to promote citizen engagement through government social media during the COVID-19 crisis. Comput Hum Behav. 2020;110:106380-106380. https://doi.org/10.1016/j.chb. 2020.106380.

73. Zhang L, Li H, Chen K. Effective risk communication for public health emergency: Reflection on the COVID-19 (2019-nCoV) outbreak in Wuhan, China. Healthcare (Basel, Switzerland). 2020;8(1):64. https://doi.org/10.3390/ healthcare8010064.

74. Roth Y, Pickles N. Updating our approach to misleading information: Twitter, Inc; 2020.

75. Pennycook G, et al. Fighting COVID-19 misinformation on social media: experimental evidence for a scalable accuracy-nudge intervention. Psychol Sci. 2020;31(7):770-80.

76. Abbasi J. Anthony Fauci, MD, on COVID-19 vaccines, schools, and Larry Kramer. JAMA. 2020;324(3):220-2.

77. Folkenflik, D. Dr. Anthony Fauci is talking to just about anyone about the coronavirus. 2020 [cited 2020 September 17]; Available from: https:/www. npr.org/2020/04/01/825499536/dr-anthony-fauci-is-talking-to-just-aboutanyone-about-the-coronavirus.

78. Cohen, J. 'I'm going to keep pushing.' Anthony Fauci tries to make the White House listen to facts of the pandemic. 2020 [cited 2020 September 17]; Available from: https://www.sciencemag.org/news/2020/03/i-m-goingkeep-pushing-anthony-fauci-tries-make-white-house-listen-facts-pandemic.

79. Chen $\mathrm{H}$, et al. Clinical characteristics and intrauterine vertical transmission potential of COVID-19 infection in nine pregnant women: a retrospective review of medical records. Lancet. 2020;395(10226):809-15.

80. Bhagavathula AS, et al. Knowledge and perceptions of COVID-19 among health care workers: cross-sectional study. JMIR Public Health Surveill. 2020; 6(2):e19160.

81. Taghrir MH, Borazjani R, Shiraly R. COVID-19 and Iranian medical students; a survey on their related-knowledge, preventive behaviors and risk perception. Arch Iran Med. 2020;23(4):249-54.

82. Olum R, et al. Coronavirus disease-2019: knowledge, attitude, and practices of health care workers at makerere university teaching hospitals, Uganda. Front Public Health. 2020;8:181.

83. Spoorthy MS, Pratapa SK, Mahant S. Mental health problems faced by healthcare workers due to the COVID-19 pandemic-a review. Asian J Psychiatr. 2020;51:102119.

84. Su Z, et al. A race for a better understanding of COVID-19 vaccine nonadopters. Brain Behav Immun Health. 2020;9:100159.

85. Tokyay, M. Pandemic threatens livelihood of Turkish musicians, driving many to suicide. 2020 [cited 2020 October 3]; Available from: https://arab. news/5vxz5.

\section{Publisher's Note}

Springer Nature remains neutral with regard to jurisdictional claims in published maps and institutional affiliations.

\section{Ready to submit your research? Choose BMC and benefit from:}

- fast, convenient online submission

- thorough peer review by experienced researchers in your field

- rapid publication on acceptance

- support for research data, including large and complex data types

- gold Open Access which fosters wider collaboration and increased citations

- maximum visibility for your research: over $100 \mathrm{M}$ website views per year

At BMC, research is always in progress.

Learn more biomedcentral.com/submissions 